\title{
Antiproliferation effects of ethanol extract of garlic peels on human cancer cell lines
}

\author{
Dae-Yeul Son* \\ Department of Biotechnology and Convergence, Daegu Haany University, Gyeongsan 38610, Korea
}

\section{마늘껍질 $70 \%$ 에탄올 추출물의 인간 암세포 증식억제 활성}

\author{
손대열* \\ 대구한의대학교 바이오산업융합학부
}

\begin{abstract}
Ethanol extract of garlic peels (GPE) was investigated for its antiproliferative effects on human cancer cell lines. Human lung cancer cell line A549 treated with $500 \mu \mathrm{g} / \mathrm{mL}$ GPE resulted in the growth inhibition of A549 by 90\%. In stomach cancer cell AGS proliferation inhibition activity, GPE showed $45 \%$ and $71 \%$ inhibition of AGS growth at $1,000 \mu \mathrm{g} / \mathrm{mL}$ and $2,000 \mu \mathrm{g} / \mathrm{mL}$, respectively. GPE inhibited the growth of the breast cancer cells MCF-7 effectively at low concentration and showed $78 \%$ and $90 \%$ inhibitions of MCF-7 growth at $200 \mu \mathrm{g} / \mathrm{mL}$ and 500 $\mu \mathrm{g} / \mathrm{mL}$, respectively. GPE showed very significant antiproliferation effect on liver cancer cell line Hep3B and inhibited Hep3B cell growth by $57 \%$ at $100 \mu \mathrm{g} / \mathrm{mL}$, and the inhibition's rate increased up to $87 \%$ at $500 \mu \mathrm{g} / \mathrm{mL}$. Antiproliferation effect of GPE on colorectal cancer cell HT-29 showed 15\% reduction of HT-29 cell growth at $200 \mathrm{\mu g} / \mathrm{mL}$ and the growth rate was reduced in a dose dependent manner up to $1,000 \mu \mathrm{g} / \mathrm{mL}$. These results indicated that GPE had high antiproliferation effects on breast and liver cancer cell lines at low concentrations $(200 \mu \mathrm{g} / \mathrm{mL})$, and by higher concentrations over $500 \mathrm{\mu g} / \mathrm{mL}$, GPE inhibited the growth of A549 and HT-29. The results of our study suggested the potential use of garlic peels for use as an excellent antiproliferative substance for human cancer cells.
\end{abstract}

Key words : antiproliferation, garlic peel, ethanol extract, human cancer cell line

\section{서 론}

100 세 시대를 앞둔 오늘날 삶의 질이 높아지면서 건강에 대한 관심과 함께 환경에 대한 인식도 높아지고 있으며, 건강에 필수적 부분인 식품에 대한 관심도 증가하고 있다. 기능성 식품에 대한 연구가 진행되면서 성인병 질환의 원인 인 활성산소를 조절할 수 있는 천연 생리활성 물질의 개발 연구가 활발히 진행되고 있다(1). 특히 성인병 질환의 대표 적인 암은 전 세계적으로 가장 널리 퍼져있는 질병으로

*Corresponding author. E-mail : dyson@dhu.ac.kr

Phone : 82-53-819-1434, Fax : 82-53-819-1272

Received 21 November 2016; Revised 6 December 2016; Accepted 9 December 2016.

Copyright (c) The Korean Society of Food Preservation. All rights reserved.
암에 의한 사망률이 가장 높고, 암에 의한 사망률은 해마다 증가하는 추세이다(2). 현재까지 많이 사용되고 있는 암 치료 방법인 방사선 및 합성 화학 약품은 인체에 강한 독성 을 나타내는 경우가 많아, 인체에 심각한 부작용을 야기한 다. 합성 의약품에 비해 독성 및 부작용이 적고 활성산소를 제어하면서 항암활성이 높은 천연 자원에 대한 관심은 더욱 높아지고 있다(3).

마늘(garlic, Allium sativum L)은 그 독특하고 강한 맛으로 음식의 맛을 좋게 하고 비린내를 없애며 식옥을 증진시키는 효과가 있어 아주 중요한 향신료로 우리 생활 속에 널리 사용되고 있으며, 예로부터 강정식품으로 우리 선조들이 널리 이용해 온 식품이다. 이렇게 오랜 세월 우리 생활 속에 서 사용되어 온 마늘이 오늘날 고혈압, 동맥경화, 허혈성 심장 질환, 뇌졸증 등의 심장 순환계 질환의 예방과 치료에 효능이 있다고 밝혀지면서 의약품으로의 활용을 위한 연구 
가 진행되고 있다(4). 마늘은 폴리페놀과 플라보노이드 및 항산화 물질이 풍부한 식품으로 알려졌다(5). Lim 등(6)은 마늘에 astragalin과 kaempferol과 비슷한 구조의 allivicin이 라는 플라보노이드가 함유되어 있다고 보고하였고, Nuutila 등(7)은 마늘에 비타민 $\mathrm{C}$ 와 비타민 $\mathrm{E}$ 의 함량이 높다고 보고 하였다. 또 다른 마늘의 유효성분으로 추정되는 물질인 allicin은 마늘 특유의 휘발성 향기 성분으로서 마늘조직이 파괴될 때 자체효소인 allinase에 의해 alliin이 분해되어 생 성되며, 혈중 지질 저하효과를 가지고 있어 사람의 혈청 중에 함유된 콜레스테롤 및 중성지방의 함량을 감소시키고 죽상동맥경화증(atherosclerosis)의 발생을 억제시키는 것 으로 보고되었다(8). 그리고 allicin이 더욱 분해되어 ajoene 으로 전환되면 강력한 항혈전 효과를 지니게 된다는 연구 보고도 있다(9). 또한 마늘은 항균 작용, 항돌연변이 작용, 칼슘 흡수의 증진, 비타민C의 보호 작용, 각기병의 치료효 능, 항산화 작용과 지구력과 스테미나 증진 작용 등의 보고 가 있다(10). 이런 연구들을 바탕으로 마늘을 단순한 향신료 가 아닌 건강식품, 의약품으로 개발하려는 다양한 시도가 이루어지고 있다(11).

마늘이 많이 재배되는 지역에서는 많은 양의 마늘껍질이 부산물로 생산되나 불쾌한 냄새와 환경을 오염시키는 쓰레 기로 버려지고 있는 실정이다. 마늘껍질의 생리활성에 대 한 연구보고에 따르면, 마늘껍질에는 마늘 육질보다 식이 섬유의 함량이 4 배, 총 페놀 함량이 7 배가량 높다고 보고하 였다(11). 이에 본 연구에서는 마늘껍질의 $70 \%$ 에탄올 추출 물의 인간 암 세포에 대한 증식 억제 활성을 연구하여 버려 지는 마늘껍질의 가치를 확인함으로써 마늘껍질을 기능성 식품이나 의약품 재료로의 재활용방안을 모색하고자 하 였다.

\section{재료 및 방법}

\section{재료 및 추출}

본 실험에 사용한 마늘껍질은 경남 창녕군 마늘공장에서 수거하였으며, 수거된 마늘껍질은 불순물과 분리 후 세척, 자연 건조하여 추출에 사용하였다. $70 \%$ 에탄올이 추출용매 로 이용되었다. $70 \%$ 에탄올 추출물은 시료 무게의 10 배 용매를 가하여 실온에서 교반하면서 24시간 동안 추출하였 고, 같은 작업을 3 번 반복하였다. 얻어진 추출액은 Whatman 1 번을 이용하여 여과하였고 회전감압농축기 $(\mathrm{N}-1000$, Eyela, Tokyo, Japan)를 이용해 농축한 후, $-20^{\circ} \mathrm{C}$ 냉동고에서 보관 하여 시료로 사용하였다.

\section{세포주 및 세포 생육 배지}

본 실험에서 사용한 암 세포주는 인체유래 폐암 세포 A549, 위암 세포 AGS, 유방암 세포 MCF-7, 간세포 Hep3B
및 대장암 세포 HT-29를 사용하였고, 정상 세포주는 인체유 래 신장 세포인 HEK293을 사용하였다. 각각의 세포는 $10 \%$ fetal bovine serum(FBS)와 $100 \mathrm{U} / \mathrm{mL}$ penicillin $\mathrm{G}, 100 \mathrm{\mu g} / \mathrm{mL}$ streptomycin을 첨가한 RPMI 1640과 DMEM, EMEM medium을 사용하여 $5 \% \mathrm{CO}_{2}, 37^{\circ} \mathrm{C}$ 조건 배양기에서 배양하 였다.

in vitro에서 정상세포에 대한 독성 및 암세포 성장 억제

추출물의 정상세포 및 암세포에 대한 독성은 Young 등 (12)의 방법에 따라 MTT assay로 확인하였다. 각 세포주를 96 well plate에 $1 \times 10^{4}$ cells/well 분주하고 24 시간 동안 배양 $\left(37^{\circ} \mathrm{C}, 5 \% \mathrm{CO}_{2}\right)$ 한 후, 전 배양에 사용된 배지를 제거하고 배지에 각각의 시료 농도로 처리하여 48시간 배양하였다. 배양이 완료된 후에 well당 $20 \mu \mathrm{L}$ 의 MTT solution $(1 \mathrm{mg} / \mathrm{mL})$ 을 첨가하여 $37^{\circ} \mathrm{C}, 5 \% \mathrm{CO}_{2}$ 배양기에서 4 시간 동안 반응시 킨 후 MTT시약이 포함된 배지를 제거하고 DMSO $100 \mu \mathrm{L}$ 를 가한 후 상온에서 발색시키고 ELISA reader를 이용하여 $550 \mathrm{~nm}$ 에서 흡광도를 측정하였다.

$$
\begin{aligned}
& \text { 세포생존율 }(\%)=\left(\frac{\mathrm{A}_{\mathrm{test}}}{\mathrm{B}_{\mathrm{control}}}\right) \times 100 \\
& \mathrm{~A}_{\mathrm{test}} \text { : 시료 첨가구의 흡광도 } \\
& \mathrm{B}_{\mathrm{control}} \text { : 시료 무첨가구의 흡광도 }
\end{aligned}
$$

\section{통계처리}

모든 데이터는 3 회 반복 측정하였으며, 평균(mean) \pm 표 준편차(SD)로 표시하였다. 실험 군 간의 통계학적 분석은 SPSS(Ver. 18.0, SPSS Inc., Chicago, IL, USA)를 이용하여 ANOVA 분석을 시행하였고, 유의차가 있는 항목에 대해서 는 신뢰구간 $\mathrm{p}<0.05$ 에서 Duncan's multiple range test를 실시 하였다.

\section{결과 및 고찰}

\section{정상세포에 대한 세포독성}

마늘껍질 $70 \%$ 에탄올 추출물(GPE)의 정상세포에 대한 독성을 측정하기 위해 인체 신장유래 정상세포(HEK 293) 를 사용하였고, 시료는 농도 $100-2,000 \mathrm{\mu g} / \mathrm{mL}$ 범위에서 독 성 여부를 측정하였다. 그 결과, GPE는 조사된 모든 농도에 서 $100 \%$ 이상의 높은 세포 생존율이 확인되어 조사된 시료 농도 $100-2,000 \mathrm{\mu g} / \mathrm{mL}$ 범위에서 마늘껍질 $70 \%$ 에탄올 추출 물은 정상세포에 독성이 없음을 확인하였다(Fig. 1).

\section{인체 유래 암세포에 대한 성장 억제}

인체에서 유래된 폐암 세포(A549), 위암 세포(AGS), 유 세포생존율 $(\%)=($ 방암 세포(MCF-7), 간암 세포(Hep3B) 


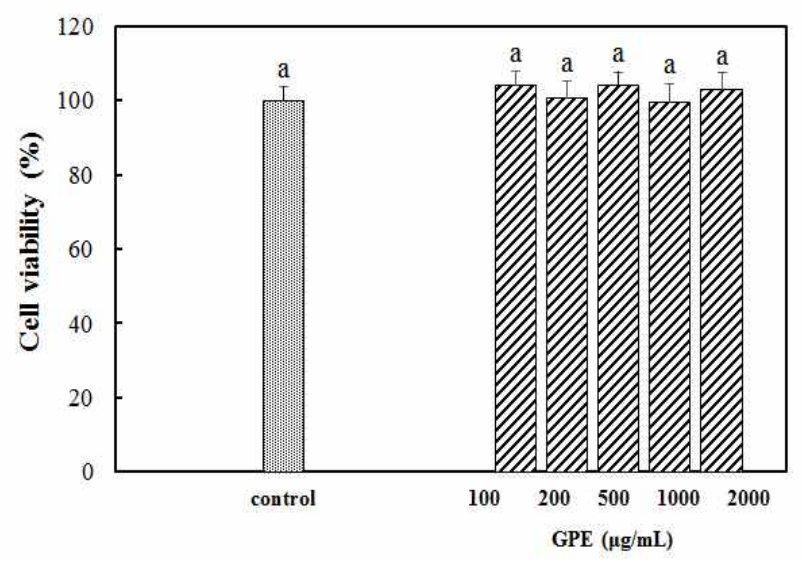

Fig. 1. Viability of human normal cell line HEK293 treated with $70 \%$ ethanol extract of garlic peels (GPE).

Cells were treated with GPE $(100-2,000 \mu \mathrm{g} / \mathrm{mL})$ for $24 \mathrm{hr}$. Cell viability was determined by MTT assay. Mean \pm standard deviation from three independent experiments are shown. Bars with the same letters are not significant different at $p<0.05$.

및 대장암 세포(HT-29)를 이용하여 GPE가 각각의 암세포 생존율에 미치는 영향을 확인하기 위해 MTT assay를 이용 하여 암세포에 대한 성장 억제 활성을 측정하였다.

폐암 세포(A549)에 대한 성장 억제 활성 측정 결과, 200 $\mu \mathrm{g} / \mathrm{mL}$ 까지의 저 농도 처리에서는 A549 세포의 생존율이 $100 \%$ 로 증식 억제 효과가 나타나지 않았다(Fig. 2A). 반면 $500 \mathrm{\mu g} / \mathrm{mL}$ 이상의 농도에서는 A549 세포의 생존율이 $10 \%$ 이하로 떨어지면서 $90 \%$ 의 우수한 폐암 세포 증식 억제 활성이 확인되었다. Hoe 등(13)은 버섯 균사체 혼합 배양 추출물 처리에 대한 A549 세포의 생존율이 $53 \%$ 라고 보고 하였고, Lee 등 $(14,15)$ 은 $1,000 \mu \mathrm{g} / \mathrm{mL}$ 농도에서 홍경천 뿌리 및 캘러스 초음파 추출물의 세포 성장률이 $37 \%$, 매자나무 수피 추출물에 대한 생존율이 $30 \%$ 라고 보고하였다. 이들 결과와 비교할 때 $500 \mu \mathrm{g} / \mathrm{mL}$ 농도에서 $10 \%$ 이하의 폐암 세포 생존율을 확인한 마늘껍질 에탄올 추출물은 폐암 세포 에 대한 성장 억제 활성이 매우 우수한 것으로 확인되었다.

인간의 위암 세포인 $\mathrm{AGS}$ 에 대한 마늘껍질 $70 \%$ 에탄올 추출물의 증식 억제 활성 조사 결과는 $\mathrm{Fig}$. $2 \mathrm{~B}$ 와 같다. 위암 세포에 대한 GPE의 성장 억제 활성은 $500 \mu \mathrm{g} / \mathrm{mL}$ 농도까지 $100 \%$ 세포 생존율이 확인되어 증식 억제 효과가 없는 것으 로 확인되었으며, $1,000 \mu \mathrm{g} / \mathrm{mL}$ 의 농도에서 $45 \%$ 의 증식 억 제율을 확인할 수 있었고, 최고 처리 농도 $2,000 \mu \mathrm{g} / \mathrm{mL}$ 에서 $71 \%$ 의 억제율을 확인하였다. Park 등(16)은 여지초 추출물 이 $1,000 \mu \mathrm{g} / \mathrm{mL}$ 농도에서 $57 \%$ 의 생존율을, $\mathrm{Kim}(17)$ 은 대추 잎 물 추출물 $1,000 \mu \mathrm{g} / \mathrm{mL}$ 농도에서 $78 \%$ 의 위암 세포 생존 율을 보고하였다. 또한 콩 종류별로 암세포 증식 억제 효과 를 비교한 $\operatorname{Lim}(18)$ 은 콩 메탄올 추출물이 $1,000 \mu \mathrm{g} / \mathrm{mL}$ 농도 에서 $50 \%$ 이상의 암세포 증식 억제 효과가 있다고 보고하 였다. 이들 결과와 비교할 때 마늘껍질 $70 \%$ 에탄올 추출물 은 상대적으로 높은 위암세포 증식 억제 활성이 있는 것으
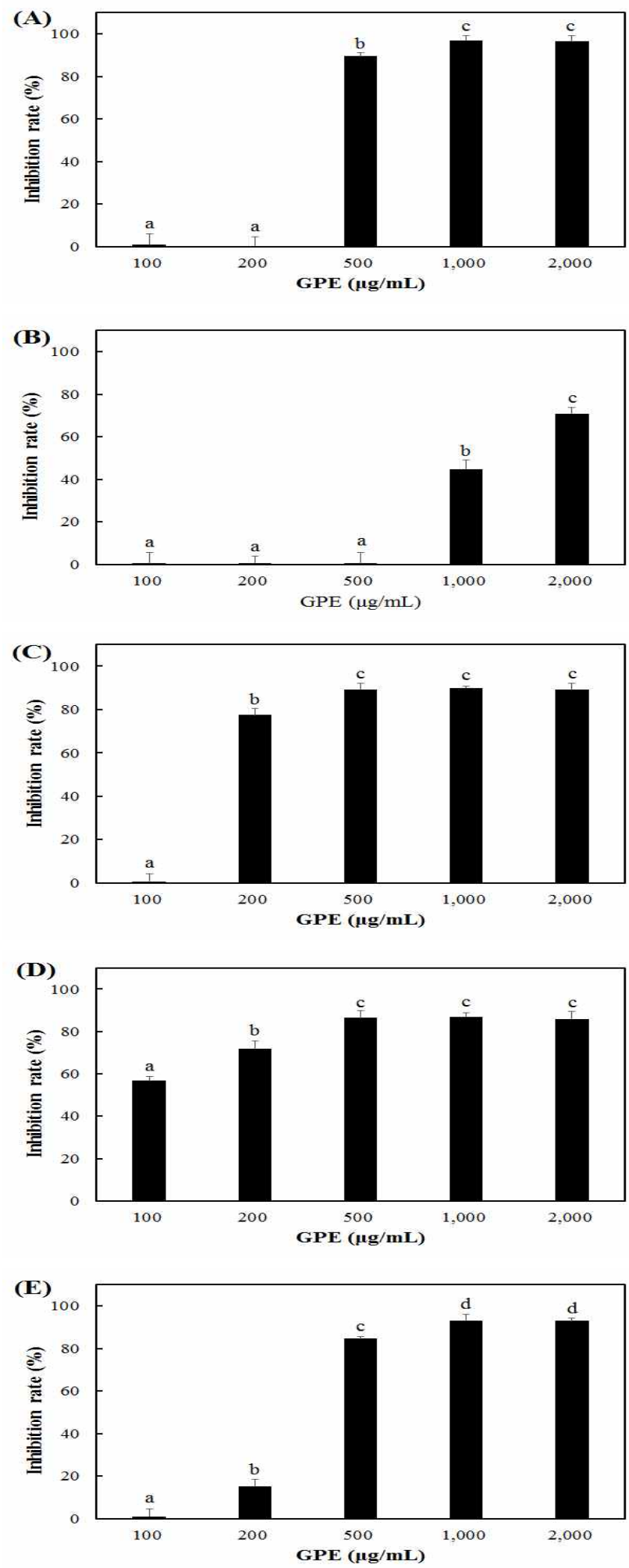

Fig. 2. Inhibition of human cancer cell growth by addition of $70 \%$ ethanol extract of garlic peels (GPE).

(A), human lung cancer cell line A549; (B), human stomach cancer cell line AGS; (C), human breast cancer cell line MCF-7; (D), human liver cancer cell line Hep3B; (E), human colorectal cancer cell line HT-29. Cells were treated with GPE (100-2,000 $\mu \mathrm{g} / \mathrm{mL}$ ) for $24 \mathrm{hr}$. Cell viability was determined by MTT assay. Mean \pm standard deviation from three independent experiments are shown. Bars with the same letters are not significant different at $\mathrm{p}<0.05$. 
로 확인되었다.

유방암과 관련해 Challier 등(19)은 마늘 성분이 유방암에 효과적임을 밝힌바 있고, Ham 등(20)은 유방암 세포에 대해 $500 \mathrm{\mu g} / \mathrm{mL}$ 농도의 산마늘 추출물에서 $71.3 \%$ 의 높은 증식 억제 활성을 보고하였다. 유방암 세포 MCF-7에 대한 GPE 의 증식 억제 활성은 폐암세포(A549)나 위암세포(AGS)에 대한 억제 활성보다 훨씬 우수한 것으로 확인되었다(Fig. 2C). 조사된 제일 낮은 농도인 $100 \mu \mathrm{g} / \mathrm{mL}$ 농도에서는 $\mathrm{GPE}$ 가 유방암 세포의 증식을 억제하는 효과를 확인할 수 없었 으나 $200 \mu \mathrm{g} / \mathrm{mL}$ 의 저 농도에서 $78 \%$ 의 유방암 세포 억제율 이 확인되어 매우 우수한 유방암 세포 증식 억제 효과가 있는 것이 확인되었다. $500 \mu \mathrm{gg} / \mathrm{mL}$ 이상의 농도 처리 결과에 서는 모두 $90 \%$ 전후의 유방암 세포 억제율을 확인하였으며 농도에 따른 유의적 차이는 없는 것으로 확인되었다. 이러 한 결과는 $\operatorname{Kim}(17)$ 이 $500 \mathrm{\mu g} / \mathrm{mL}$ 농도에서 대추잎 $70 \%$ 에탄 올 추출물에 대해 $69 \%$ 의 생존율을 보고한 것과, Kwon 등 (21)이 $1,000 \mu \mathrm{g} / \mathrm{mL}$ 농도에서 상황버섯 균사체 에탄올 추출 물에 대한 암세포 생존율이 $81 \%$ 라고 보고한 것과 비교할 때, 마늘껍질 $70 \%$ 에탄올 추출물은 저 농도에서도 매우 높은 유방암 세포 증식 억제 활성이 있는 것이 확인되었다.

농도별 GPE 처리에 대한 간암 세포(Hep3B)의 증식억제 활성을 조사한 결과는 Fig. $2 \mathrm{D}$ 와 같다. 마늘껍질 $70 \%$ 에탄 올 추출물이 $100 \mathrm{\mu g} / \mathrm{mL}$ 의 저 농도에서 다른 암세포의 증식 을 억제하지 못한 반면, 간암 세포의 경우 $100 \mathrm{\mu g} / \mathrm{mL}$ 의 저 농도 처리에서도 $57 \%$ 의 억제율이 확인되어, $\mathrm{GPE}$ 의 매 우 우수한 간암 세포 증식 억제 활성이 확인되었다. 처리되 는 $\mathrm{GPE}$ 의 농도가 증가함에 따라 $500 \mu \mathrm{g} / \mathrm{mL}$ 농도까지 농도 의존적으로 간암 세포에 대한 증식 억제 활성은 증가되어 간암 세포의 생존율이 $13 \%$ 까지 저하되었으며, $500 \mathrm{\mu g} / \mathrm{mL}$ 이상의 농도에서는 처리 농도에 따른 유의적 차이는 없는 것으로 확인되었다. $\operatorname{Lim}(18)$ 이 보고한 흑태, 서목태 및 서리 태 메탄올 추출물이 $1,000 \mathrm{\mu g} / \mathrm{mL}$ 의 상대적으로 높은 농도 에서 $51 \%, 59 \%$ 및 $52 \%$ 의 증식 억제 효과를 확인한 반면, 본 연구에서 조사된 $\mathrm{GPE}$ 는 $100 \mathrm{\mu g} / \mathrm{mL}$ 의 저 농도에서 $57 \%$ 의 높은 생존 억제 효과가 확인되어 GPE가 다른 암세포보 다 특히 간암 세포에 대한 증식 억제 효과가 탁월함을 확인 하였다.

대장암 세포(HT-29)에 대한 증식 억제 효과는 유방암 세포(MCF-7)에서 확인된 GPE의 증식억제 활성 결과와 유 사하게 확인되었다. $100 \mu \mathrm{g} / \mathrm{mL}$ 농도 처리에서는 HT-29 세 포에 대한 증식 억제 효과가 확인되지 않았으며, $200 \mathrm{\mu g} / \mathrm{mL}$ 의 저 농도 처리에 $15 \%, 500 \mathrm{\mu g} / \mathrm{mL}$ 농도 처리에서 $85 \%$, $1,000 \mathrm{\mu g} / \mathrm{mL}$ 의 고농도 처리에서 $93 \%$ 의 대장암 세포 증식 억제율을 확인하였으며, 조사된 $1,000 \mathrm{\mu g} / \mathrm{mL}$ 농도까지 농 도 의존적으로 대장암 세포에 대한 생장 억제 효과가 있는 것으로 확인되었고, $1,000 \mathrm{\mu g} / \mathrm{mL}$ 이상의 농도 처리에서는 농도에 따른 유의적 차이가 없는 것으로 확인되었다.

\section{요 약}

버려지는 마늘껍질의 자원으로써의 활용 가치를 확인하 기 위해 마늘껍질 $70 \%$ 에탄올 추출물(GPE)을 이용하여 인체에서 유래된 폐암 세포(A549), 위암 세포(AGS), 유방 암 세포(MCF-7), 간암 세포(Hep3B) 및 대장암 세포(HT-29) 의 생존율에 미치는 영향을 확인하였다.

폐암 세포(A549)의 경우 $200 \mathrm{\mu g} / \mathrm{mL}$ 의 저 농도에서는 $\mathrm{A} 549$ 세포의 생존율이 $100 \%$ 로 증식 억제 효과가 나타나지 않았으나 $500 \mu \mathrm{g} / \mathrm{mL}$ 이상의 농도에서는 A549 세포의 생존 율이 $10 \%$ 이하로 떨어지면서 우수한 폐암 세포 증식 억제 활성이 확인되었다.

위암 세포에 대한 조사에서는 $1,000 \mathrm{\mu g} / \mathrm{mL}$ 의 농도에서 $55 \%$ 의 생존율을 확인할 수 있었고, 최고 $2,000 \mu \mathrm{g} / \mathrm{mL}$ 의 농도에서 $71 \%$ 의 위암 세포 증식 억제활성이 확인되었다.

유방암 세포(MCF-7)의 경우 $200 \mu \mathrm{g} / \mathrm{mL}$ 의 저 농도에서 $78 \%, 500 \mu \mathrm{g} / \mathrm{mL}$ 이상의 농도 처리 결과에서는 모두 90\% 전후의 유방암 세포 증식 억제활성이 확인되었다.

간암 세포의 경우 $100 \mathrm{\mu g} / \mathrm{mL}$ 의 저 농도에서도 $57 \%$ 의 억제 활성이 확인되어, GPE의 매우 우수한 간암 세포 증식 억제 활성이 확인되었고, 처리되는 $\mathrm{GPE}$ 의 농도가 증가함에 따라 $500 \mathrm{\mu g} / \mathrm{mL}$ 농도까지 농도 의존적으로 간암 세포에 대한 증식 억제 활성은 증가되어 간암 세포의 생존율이 $13 \%$ 까지 저하되었다.

대장암 세포(HT-29)의 경우 $200 \mathrm{\mu g} / \mathrm{mL}$ 의 저 농도 처리에 서 $15 \%, 500 \mu \mathrm{g} / \mathrm{mL}$ 농도 처리에서 $85 \%, 1,000 \mu \mathrm{gg} / \mathrm{mL}$ 의 고농도 처리에서 $93 \%$ 의 간암세포 증식 억제율이 확인되었 으며, 농도 의존적으로 간암 세포에 대한 생장 억제 효과가 있는 것으로 확인되었다.

이상의 결과를 종합해 볼 때 마늘껍질 $70 \%$ 에탄올 추출 물 $\mathrm{GPE}$ 는 조사된 제일 낮은 농도 $(100 \mu \mathrm{gg} / \mathrm{mL})$ 에서도 간암 세포의 증식을 $57 \%$ 억제하는 우수한 활성이 확인되었고, $200 \mathrm{\mu g} / \mathrm{mL}$ 의 저 농도 범위에서는 유방암과 간암 세포의 증식을 $72-78 \%$ 억제하는 높은 활성이 확인되었으며, 500 $\mu \mathrm{g} / \mathrm{mL}$ 이상의 농도에서는 위암 세포를 제외한 조사된 4종 류의 암세포(폐암, 유방암, 간암 및 대장암 세포)의 증식을 85-90\% 억제하는 우수한 활성이 확인되었다.

본 연구의 결과를 통해 마늘 가공 과정에서 쓰레기로 버려지고 있는 마늘껍질은 $70 \%$ 에탄올 추출을 통해 유방암 (MCF-7), 폐암(A549), 위암(AGS), 유방암(MCF-7) 및 간암 (Hep3B) 세포의 성장을 억제하는 활성 물질로서의 재활용 가치가 높은 것으로 확인되었다.

\section{References}

1. Lee HB, Kim HJ, Chong MS, Cho HE, Choi YH, Lim 
KS, Lee KN (2008) Physiological activity of extracts from mixed culture of medical herbs and mycelia of Tricholoma matsutake and Cordyceps militaris by fermentation. Kor J Herbology, 23, 1-8

2. Min KJ, Cheon JU, Cha CG (2008) Anti-oxidative and anti-cancer activities of extraction of Yacon. J Fd Hyg Safety, 23, 163-168

3. Nam SH, Yang MS (1995) Isolation of cytotoxic substances from Chrysanthemum boreale M.. J Korean Soc Appl Biol Chem, 38, 273-277

4. Wu CC, Sheen LY, Chen HW, Tsai SJ, Lii CK (2001) Effects of organosulfur compounds from garlic oil on the antioxidation system in rat liver and red blood cells. Food Chem Toxicol, 39, 563-569

5. Beak KH, Kim SS, Tak SB, Kang BS, Kim DH, Lee YC (2006) Quality characteristics of garlic suspensions using protopectin hydrolytic enzymes. Korean J Food Preserv, 13, 351-356

6. Lim SC, Park HJ, Yun SY, Lee MS, Kim WB, Jung WT (1996) Structures of flavonoids and furostanol glycosides isolated from the bulbs of Allium victorialis L.. J Kor Soc Hort Sci, 37, 675-679

7. Nuutila AM, Puupponen-Pimia R, Aarmi M, OksmanCaldentey K (2003) Comparison of antioxidant activities of onion and garlic extracts by inhibition of lipid peroxidation and radical scavenging activity. Food Chem, $81,485-493$

8. Jo HJ, Choi MJ (2002) Effect of $1 \%$ garlic powder on serum and liver lipid and plasma amino acid concentration in rats fed cholesterol diet. J Korean Soc Food Sci Nutr, 31, 98-103

9. Steiner M, Li W (2001) Aged garlic extract, a modulator of cardiovascular risk factors: a dose-finding study on the effects of AGE on platelet functions. J Nutr, 131, 980S-984S

10. Kim HK, Kwak HJ, Kim KH (2002) Physiological activity and antioxidative effect of garlic (Allium sativum L.) extract. Food Sci Biotechnol, 11, 500-506

11. Kim RJ, Kang MJ, Lee SJ, Shin JH, Sung NJ (2010) Physicochenmical characteristics and antioxidant activities of fermented garlic husk. J Korean Soc Food Sci Nutr, $39,1731-1738$
12. Young FM, Phungtamdet W, Sanderson BJS (2005) Modification of MTT assay conditions to examine the cytotoxic effects of amitraz on the human lymphoblastoid cell line, WIL2NS. Toxocol In Vitro, 19, 1051-1059

13. Kim MC, Kim JS, Heo MS (2008) Antibacterial, antioxidant and antitumor activities of mushroom mycelium mixed culture extracts. Korean J Biotechnol Bioeng, 23, 158-163

14. Ha JH, Jeong HS, Jeong MH, Kim SS, Jin L, Nam JH, Hwang B, Ma CJ, Lee HY (2009) Comparison of anticancer activities of ultrasonification extracts of callus and roots from Rhodiola sachalinensis A. Bor. Korean J Food Sci Technol, 41, 552-559

15. Jin L, Ha JH, Jeong MH, Chung EK, Chung AR, Kim JC, Ahn JH, Lee HY (2009) Enhancement of the antioxidant and anticancer activities of Berberis koreana Bark by using a low temperature and high-pressure extraction process. Korean J Food Sci Technol, 41, 284-291

16. Bae MJ, Ye EJ, Kim SJ, Kim JM, Yee ST, Park EM (2007) The effects of Plebeian Herba (Salvia prebeia $\mathrm{R}$. Br.) on the anticancer (in vitro) and activation of immune cells. J Korean Soc Food Sci Nutr, 36, 377-382

17. Kim YJ, Son DY (2011) Hot water leaves extracts of Zizyphus jujube exert antioxidative effects in vitro and cytotoxicity in human cancer cell lines. Hortic Environ Biotechnol, 52, 635-640

18. Lim SY (2010) Comparison of effect of various types of soybeans on mutagenicity and growth of human cancer cell lines. J Life Sci, 20, 1532-1537

19. Challier B, Perarnau JM, Viel JF (1998) Garlic, onion and cereal fibre as protective factors for breast cancer: a French case-control study. Eur J Epidemiol, 14, 737-747

20. Ham SS, Cui CB, Choi HT, Lee DS (2004) Antimutagenic and cytotoxic effects of Allium victorialis extracts. Korean J Food Preserv, 11, 221-226

21. Kwon SH, Kim CN, Kim CY, Kwon ST, Park KM, Hwangbo S (2003) Antitumor activities of protein-bound polysaccharide extracted from mycelia of mushroom. Korean J Food Nutr, 16, 15-21 